\title{
通勤線区における回生有効率と閑散線区における 回生有効率及びその向上策の研究
}

\author{
正員 杉本 健 （前 財团法人 鉄道総合技術研究所）
}

\section{A Study on Effective Coefficient of Regenerative Energy for Commuting Sections and Deserted Railways, and Its Improvement Plan for the Latter. \\ Takeshi Sugimoto, Member (Pre Railway Technical Research Institute)}

\begin{abstract}
All vehicles used for commuting and deserted sections are the inverter control regenerative brake types. For the purpose of energy saving and maintenance, it is very important to grasp the value of effective coefficient of regenerative energy (the ratio of the regenerative energy to the total brake energy) in actual operation. Field tests proved that the value of effective coefficient of regenerative energy was quite low at deserted sections, while it was satisfactory high at commuting sections. It is required to discuss measures to improve the coefficient of regenerative energy for deserted sections. Therefore, we simulated measures to shorten lengths of train composition and to equip substations with inverters and a tie-feeding system.

Inverter control vehicles are used AC traction motors. On the other hand, the feeding system is direct current. therefore the alternating current of these must be changed into direct current. We theoretically defined the technique to change the $\mathrm{AC}$ electric power of those into $\mathrm{DC}$ electric power at the simulation.
\end{abstract}

キーワード: 直流き電システムム，回生車兩，回生有効率

1. はじめに

現在，通勤線区においても，閑散線区においても新製車両 はすべてインバータ制御の回生車両である。この回生車両の 運転時における回生有効率（回生電力量／回生可能電力量） を把握し, 向上させることは省エネルギー上及びメインテナ ンス上極めて重要である。本論文において初めて通勤線区及 び閑散線区において回生有効率の実測を行った。測定した通 勤線区においては回生有効率は高くほとんど問題はなかっ た。閑散線区においては回生有効率がかなり低く対策が必要 であることがわかった。回生有効率向上のため, 車雨編成長
を短縮したり，各変電所にインバー夕装置を設定したり，電 車線路抵抗を低減したり，上下タイ・上下一括き電方式，高 電圧化を行った場合の研究をシミュレーションによりおこ なった。測定した通勤線区・閑散線区の回生有効率は前述し た通りであり，一般的な傾向である。しかし具体的には，各 通勤線区・閑散線区において列車本数, 車両編成長などまち まちであるため, 各線区ごとに具体的に回生有効率を把握し た上で，対策などをたてて行く必要がある。

またシミュレーションをおこなうためには車両システム を適切にモデル化しなければならない。パンタ点電圧が変 
われば引張力・制動力の特性も変化する。このため, パン 夕点電圧が変化した時にそれが引張力・制動力に与える影 遙を分析した。またインバータ制御車両は主電動機に交流 電動機を採用しているが，き電回路は直流であるため，主 電動機に入出力する電力を直流電力に変換しなければなら ない。このため直流電力に変换する方法を理論的に明確化 した。

\section{2. インバータ制御車両のモデル化}

インバータ制御車両の特性として, 速度一引張力特性が ある。この特性性，性能值（性能が註験で保証されている） として車両取投説明書(1)などに示されている。しかしながら， 一般的にこれらの特性はパンタ点電圧が一定の定格電圧で の特性である。パンタ点電圧は时々刻々変化しており，パ ンタ点電圧が変わることによりこれらの特性は変化するた め, パンタ点電圧に応した動的な速度一引張力特性を求め なければならない。このため，今後大幅に使用されると考 えられるインバータ制御車両の例として 209 系車両でパン タ点電圧に応じた引張力・制動力特性を検討した。

<2・1> パンタ点電圧の変化にともなう引張力・制動力 の特性 209 系車両 $(1)(2)(3)(4)(5)$ の主回路構成住, 図1の之お りである。力行時はパンタグラフからの直流電力は, フィ ルタリアクトルを通りインバータユニットにより可変周波 数可変電圧の三相交流電力に変換され，これにより誘道電 動機が、駆動される。回生時は, 誘導電動機は誘導発電機と なり回生制動力を発生し, 生じた交流電力は, 直流電力に 変換し電車線側一返される。フィルタリアクトルとフィル タコンデンサを組み合わせることによって，インバータユ ニットで発生した高調波成分が除去される。

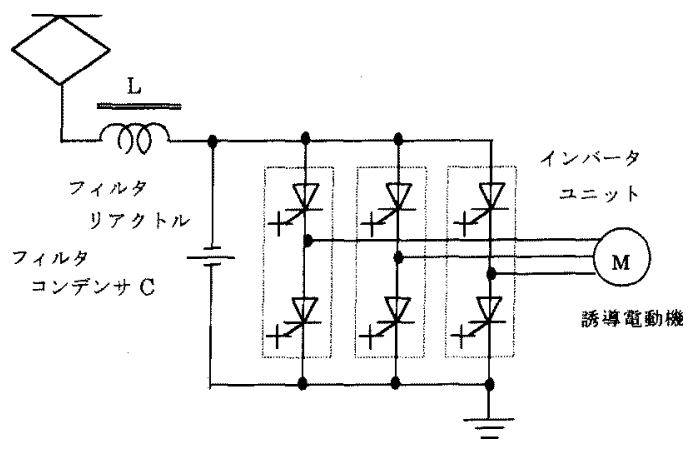

図 1 インバータ制御車両の主回路構成の例

Fig.1 Example of main circuit composition of inverter control vehicle
図 2 (2)のとおり，力行時においては，速度の上昇に伴い， 主電動機電圧を制御することにより回転磁束を一定に保ち， かつ滑り周波数も一定に保ち主電動機の定トルク制御をお こなう。主電動機電圧が最大值になれば，滑り周波数を制 御することにより主電動機電流を一定に保ち, 主電動機の 定出力制御をおこなう。滑り周波数が限度值に到達後は, 主電動機電圧は最大值で, 滑り周波数は限度値の特性領域 にはいる。

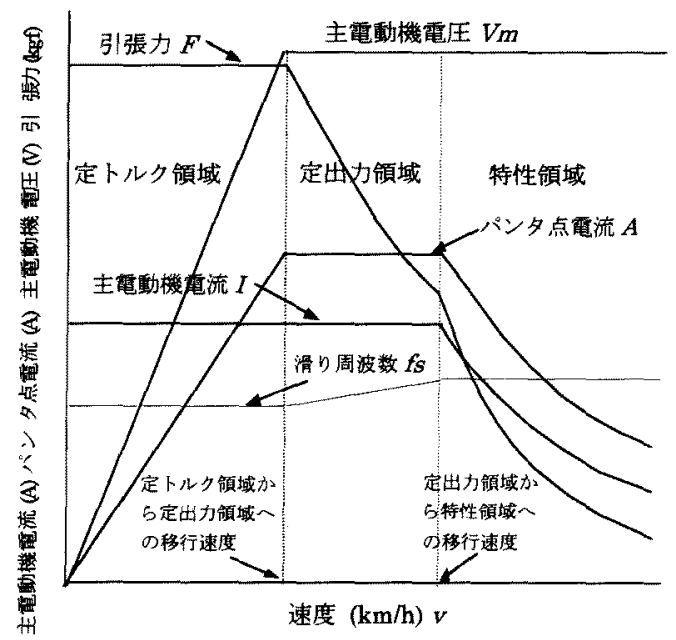

図 2 インバー夕制御車両の力行特性（概念図）

Fig.2 Powering characteristic of inverter control vehicel (concept figure)

回生時は図 $3^{(2)}$ のと扝り, 速度の上升に伴い, 主電動機電 圧を変えることにより回転磁束を一定に保ち，また滑り周 波数も一定に保ち，定トルク制御をおこなう。主電動機電 圧が最大値になった後は, 滑り周波数を変えることにより 主電動機電流も変え, 定トルク制御をおこなう。滑り周波 数が限度值に到達後は, 主電動機電圧は最大値で, 滑り周 波数は限度值の特性領域にはいる。209 系車両においては 定トルク領域の拡大をはかり減速力を大きくするようにし ている。

誘導電動機のトルク, 引張力, 電圧, 電流, 電源周波数 の関保は滑り周波数の低い範囲では下式で記述できる。

$$
\begin{aligned}
T & =k_{1} \cdot \Phi \cdot I \ldots \ldots \ldots \\
\Phi & =k_{2} \cdot V m / f \ldots \ldots \ldots \\
I & =k_{3} \cdot \Phi \cdot f_{s} \ldots \ldots \\
N & =120 \cdot\left(f-f_{s}\right) / P \\
V & =k_{4} \cdot N \ldots \ldots \ldots \ldots
\end{aligned}
$$




$$
F=k_{5} \cdot T
$$

ここで, $T:$ 主電動機のトルク $(\mathrm{N} \cdot \mathrm{m}), \Phi:$ 主電動 機の回転磁束 $(\mathrm{Wb}), I:$ 主電動機の電流 $(\mathrm{A})$,

$V m$ : 主電動機電圧 $(\mathrm{V}), F$ : 主電動機の引張力 $(\mathrm{kgf})$, $f:$ 主電動機の電源周波数 $(\mathrm{Hz}), f_{s}$ : 主電動機の滑 り周波数 $(\mathrm{Hz}), V n:$ パン夕点電圧 $(\mathrm{V}), v:$ 車両速 度 $(\mathrm{km} / \mathrm{h}), P:$ 主電動機の極数 $(-), N$ : 主電動 機の回転数 $(\mathrm{rpm}), k_{1}, k_{2}, k_{3}, k_{4}, k_{5}$ 仙定数(-)

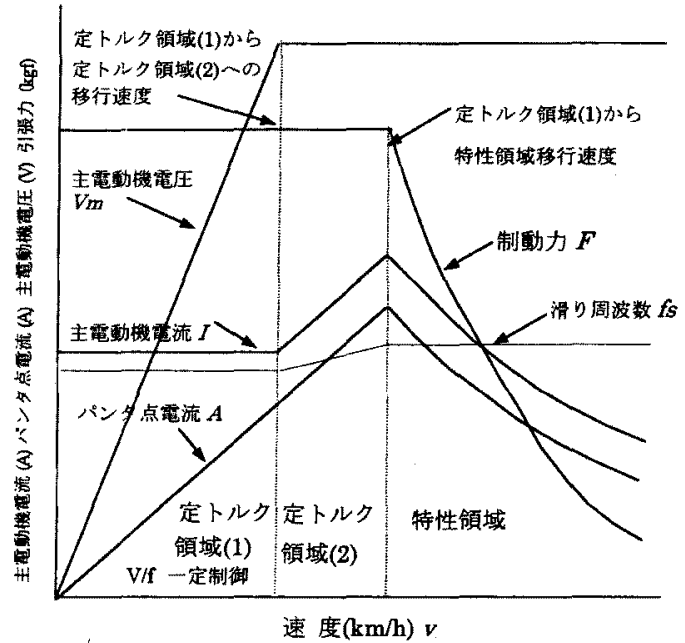

図 3 インバータ制御車両の回生制動特性（概念図）

Fig.3 Braking characteristic of inverter control vehicle (concept figure)

(1) 力行時の特性

(a) 定トルク領域

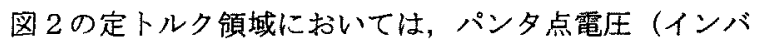
一タ制御車両においてはフィルタコンデンサ電圧と記述す るのが正確であるが, 統一をとり本論文ではパンタ点電圧 とする。）が $1500 \mathrm{~V}$ から Vnに変化しても，(2)式において 回転磁束が一定になるように主霄動機電圧が制御される。 また，滑り周波数は一定のため(3)式において主電動機電流 も変わらない。このため(1)，(6)式から求められるトルク・ 引張力はパンタ点電圧 $1500 \mathrm{~V}$ のきと変わらない。

(b) 定出力領域

図 2 の定出力領域においては，パン夕点電圧が $1500 \mathrm{~V}$ か らVnに変化しても，主電動機電流が一定になるように滑り 周波数が制御される。また力行時は, 主電動機電圧は $1100 \mathrm{~V}$ で飽和する。このため, パン夕点電圧 $V n$, 速度 $v_{1}$, 電源
周波数 $f_{1}$ ，滑り周波数 $f_{s l}$ に㧧いても回転磁束は(2)式加 次式となる。

$$
\begin{aligned}
\Phi_{1} & =k_{2} \cdot 1100 \cdot(\mathrm{Vn} / 1500) / f_{1} \\
& =k_{2} \cdot 1100 /\left(f_{1} \cdot 1500 / V n\right)
\end{aligned}
$$

さて， $f_{0}$ を次式とする。

$$
f_{0}=f_{1} \cdot 1500 / V n
$$

そうすればこの領域においては主電動機電流は一定で制 御されるため, パンタ点電圧 $V n$ の時の引張力は, (1), (7), (8)式よりパンタ点電压 $1500 \mathrm{~V}$, 電源周波数 $f_{0}$ の引張力と なる。

今，パンタ点電圧を $1500 \mathrm{~V}$, 電源周波数 $f_{0}$ の時の速度を $v_{0}$ ，滑り周波数を $f_{s 0}$ とすれば，主電動機電流が一定に制 御されるため(2)，(3)式より，

$$
f_{s 0} \cdot 1500 / f_{0}=f_{s 1} \cdot V n / f_{1}
$$

となる。

(9)式に(8)式を代入すれば, 次式のとおり滑り周波数は同じ となる。

$$
f_{s 0}=f_{s 1}
$$

また， $f_{1}$ に比して $f_{s 1}$ は小さく，かつVnは $1500 \mathrm{~V}$ に近い 加,

$$
\begin{aligned}
& v_{0}=k_{4} \cdot 120 / \mathrm{P} \cdot\left(f_{0}-f_{s 0}\right)=k_{4} \cdot 120 / \mathrm{P} \cdot\left(f_{0}-f_{s 1}\right) \\
& =k_{4} \cdot 120 / P \cdot 1500 / V n \cdot\left(f_{1}-f_{s 1}+f_{s 1} \cdot(1 \cdot V n / 1500)\right) \\
& \simeq 1500 / V n \cdot v_{1}
\end{aligned}
$$

となる。

よってパンタ点電圧が $1500 \mathrm{~V}$ から Vnになれば, パンタ 点電圧 $1500 \mathrm{~V}$ の速度一引張力特性において速度 $v_{0}$ のときの 引張力を採用すればよい。

(c) 特性領域

図 2 の特性領域においては，滑り周波数は一定になるよ うに制御される。パンタ点電圧が $1500 \mathrm{~V}$ から Vnになれば 回転磁束は，(7)式であらわされる。

この領域においては滑り周波数一定で制御されるため, 回転磁束が同じであれば主電動機電流も同じとなり，回転 磁束と主電動機電流の積に比例するトルク・引張力も同じ になる。今 $f_{0}$ を(8)式で定義しているため, パンタ点電圧 $V n$ の時の引張力は, パン夕点電圧 $1500 \mathrm{~V}$, 電源周波数 $f_{0}$ と同 じ引張力となる。

この領域では, 滑り周波数 $f_{s 0}, f_{s 1}$ は数 $\mathrm{Hz}$ であり,一 定に保たれ同じであり，また $f_{0}, f_{1}$ に比して小さく $V n$ は $1500 \mathrm{~V} に$ 近い。したがって(11)式と同様になる。

よって, 定出力領域と同様にパンタ点電圧 $1500 \mathrm{~V}$ から Vn 
になれば，パンタ点電圧 $1500 \mathrm{~V}$ の速度一引張力特性におい て速度 $v_{0}$ のときの引張力を採用すればよい。

以上を総合すれば，図 4 にあるようにパンタ点電圧が定

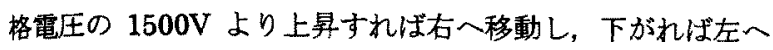
移動する。なお正規化は，パン夕点電圧が定格電圧の1500V の場合で，定トルク領域の引張力を 1.0 と寸る，速度は最高 速度を 1.0 とする。

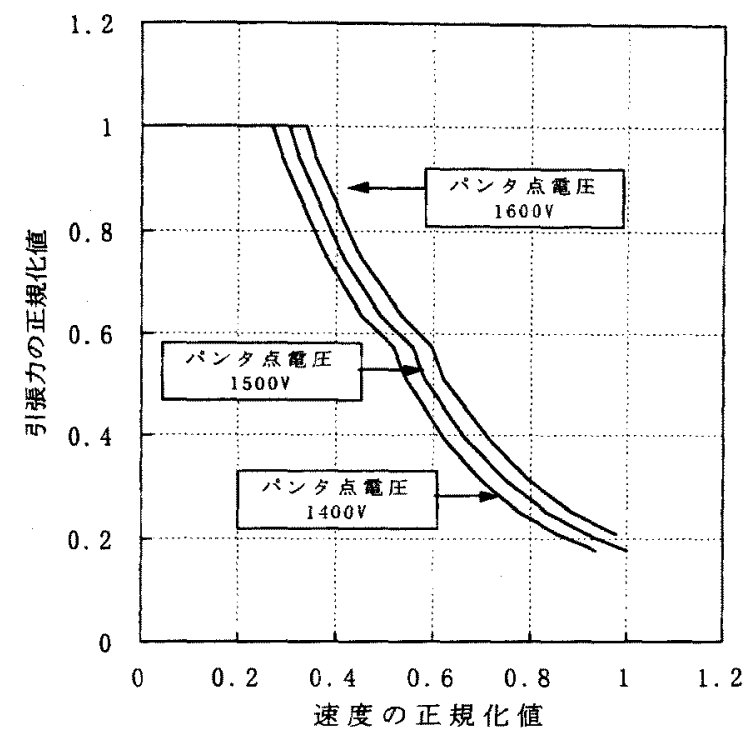

図 4 パンク点電圧を変えた時の速度一引張力特性 (209 系車両)

Fig. 4 Speed-traction characteristic for different pantograph voltage (type 209 inverter control car)

\section{（2）回生時の特性}

回生時の制御モードも力行時とほぼ同様のモードである が，209 系車雨においては高速からの有効な制動力を得る ために，図3のように定出力領域をなくし，定トルク領域 の搪大を図っている。定トルク領域を 2 つに分け，回転磁 束一定領域を定トルク領域(1); 他の領域を定トルク領域(2) とする。

(a) 定トルク領域 (1)

回生時の特性は力行時の定トルク領域と同様の特性であ ク，パンタ点電圧 $1500 \mathrm{~V} の$ 速度一制動力特性となる。

(b) 定トルク領域(2)

定トルク領域においては, パンタ点電苼が $1500 \mathrm{~V}$ から Vn に変化しても，回生制動力は一定になるように滑り周波数
が制御されるため，パンタ点電圧 $1500 \mathrm{~V}$ のとをと変わらな い。そのため制動力は，定トルク領域(1)と同様になる。

(c) 特性領域

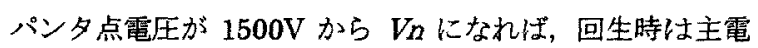

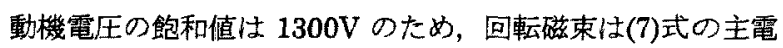
動機電圧の最大值の $1100 \mathrm{~V}$ を $1300 \mathrm{~V}$ に置き換えて表わすこ とができる。そして，力行時の特性領域と同様にパンタ点 電圧が $1500 \mathrm{~V}$ から Vnになれば, $1500 \mathrm{~V}$ の時の速度一制動 力特性において速度 $v_{0}$ のときの制動力を採用すればよい。

$<2 \cdot 2>$ 直流電力への変換 インバータ制御車両の主 電動機は交流電力が使われているが，直流き電回路は直流 電力が使われているため, 交流電力を直流電力に変換しな ければならない。一般的にインバータ制御車両のパンタ点 電圧が定格電圧の速度一引張力特性, 速度一制動力特性は 与えられている。図 5 の通りである(2)。なお正規化は入力電 力が定出力領域の時を 1.0 とする。また，速度は最高速度の 時を 1.0 とする。前節においてパンタ点電圧が変わった時の 引張力・制動力を求めた。ここではこの引張力・制動力から パンタ点電流を求める。

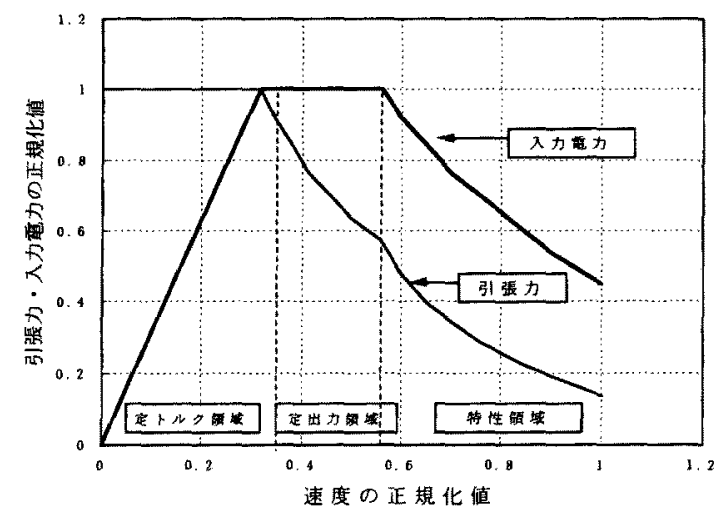

図 5 速度一入力電力特性

Fig. 5 Speed-input power characteristic of inverter control vehicle

一般的に主電動機の機械出力は下記の通り計算できる。 $P_{0}=v \cdot F / 367.2$

ここで, $P_{O}:$ 主電動機機械出力 $(\mathrm{kW})$, $v:$ 速度 $(\mathrm{km} / \mathrm{h})$,

367.2 : 変換係数 $(\mathrm{kgf} \rightarrow \mathrm{N}, \mathrm{km} \rightarrow \mathrm{m}$, 時間 $\rightarrow$ 秒) 主電動機機械出力をモータ効率，インバータ効率，ギヤ効 率，及びパンタ点電压で除すると下記の通り直流入力電流 
（以降パンタ点電流と述べる。）となる

$$
I p=P_{I} \cdot 1 / \eta_{1} \cdot 1 / \eta_{2} \cdot 1 / \eta_{3} \cdot 1 / V n
$$

ここで, Ip : パンタ点電流(A), $\eta_{1}$ : モータ効率(-),

$$
\eta_{2}: \text { インバータ効率(-), } \eta_{3}: \text { ギヤ效率(-) }
$$

ギア効率は速度が変わっても大きな変化はない。モータ 効率・インバー夕効率は速度とともにかなり変化がある。

回生有効率の比較検討，き電システムの比較検討などが このシミュレーションの目的てある。速度などの走行条件 は同一にして検討を行うため，ギヤ効率，モー夕効率，イ ンバータ効率を一定として比較しても，厳密に計算した時 に比較して大差がないと考えられ，このシミュレーション の使用目的から考慮して十分妥当であると考えられる。

また同様に回生時の主電動機の機械入力は下記の通りで ある。

$$
P_{I}=V \cdot F_{B} / 367.2
$$

ここで, $P_{I}:$ 主電動機機械入力 $(\mathrm{kW}), F_{B}$ : 制動力 $(\mathrm{kgf})$ 主電動機機械入力にモータ効率, インバータ効率，ギア 効率を乗じ，パンタ点電圧で除すると下記の通りパンタ点 電流となる。

$$
I p=P_{I} \eta_{1} \cdot \eta_{2} \cdot \eta_{3} \cdot 1 / V_{n}
$$

このような手法でインバータ制御車雨のモデル化を行っ ても基本的に問題ないと考える。以降シミュレーションに おいてはインバータ制御車両においてこのモデル化によっ てシミュレーションをおこなう。

なお，JR 中央東線においては EC351 系インバー夕制御 車両が使われているが，基本的な特性は 209 系インバータ 制御車両と同様であり，EC351 系インバータ制御車両のシ ミュレーションはこの章のモデル化した手法でおこなう。

\section{3．通勤線区における回生有効率}

$<3 \cdot 1>$ 実測結果 1996 年 12 月 $10 ， 13 ， 16$ 日にお いて表 1 の通り大宮〜蒲田間に的いて回生有効率の測定を おこなった。パンタ点電圧を測定し，その結果から回生有 効率を計算した。回生制動時のパンタ点電圧の測定結果は 表 2, 図 6 の通りである。12月 10 日に若干回生失効がある ものの，3 日の平均では回生有効率はほぼ 100\%であり，回 生失効はほ上んどなかった。また完全失効電圧 $1790 \mathrm{~V}$ 以上 の度数はほとんどなかった。図 7 に制動位置と制動時の平 均パンタ点電圧を示す。大宮から東京方面に移動するにつ れてパン夕点電圧が低下する様子がわかる。これは東京付
近は 3 複線になっていることもあり，回生車の近辺に力行 車が走行している確率が高いため，制動時のパンタ点電圧 が低くなると考えられる。一方大宮付近は 2 襍線程度であ り，回生車の近くに力行車が走行している確率が低いため， 制動時のパンタ点電圧が比較的高くなると考えられる。し かしながら回生失効には忹とんど到っていない。

表 $1 \mathrm{JR}$ 京浜東北楾における回生有勃率測定の試験概要

\begin{tabular}{|c|c|}
\hline $\begin{array}{l}\text { 日時 } \\
\text { 時間帯 }\end{array}$ & $\begin{array}{l}1996 \text { 年 } 12 \text { 月 } 10 \text { 日(次), } 13 \text { 日(金)，16 日(月) } \\
10 \text { 時 } 30 \text { 分 } 16 \text { 時 } 00 \text { 分 }\end{array}$ \\
\hline 線区 & JR 京浜東北線 大宫 蒲田間 $(44.7 \mathrm{~km})$ \\
\hline 車両 & 209 系インバー夕制御車両 (4M6T) \\
\hline 行程 & 大宮～蒲田間 2 往復 $/$ 日 \\
\hline 回生失効電圧 & $\begin{array}{l}\text { 压 失効開始電圧 } 1765 \mathrm{~V} \\
\text { 完全失効電压 } 1790 \mathrm{~V} \\
(1765 \sim 1790 \mathrm{~V} \text { 間は比例でしぼり込む) }\end{array}$ \\
\hline
\end{tabular}

Table 1. Outline of the test measure the effective coefficeint of regenerative energy at the $J R$ Keihintohoku line

\begin{tabular}{|c|c|c|c|c|c|}
\hline 平均電压箕困 $(v)$ & 12月10日 & 12月13日 & 12 月16日 & total & \\
\hline $1200-1225$ & 0 & 0 & 0 & 0 & 08 \\
\hline $1225-1425$ & 0 & 1 & 0 & 1 & $0 \%$ \\
\hline $1425-1450$ & 0 & 0 & 0 & 0 & $0 \%$ \\
\hline $1450-1475$ & 0 & 10 & 0 & 10 & o\% \\
\hline $1475-1500$ & 0 & 10 & 1 & 11 & $0 \%$ \\
\hline $1500-1525$ & 4 & 34 & 8 & 46 & $1 *$ \\
\hline $1525-1550$ & 28 & 53 & 27 & 108 & $2 \%$ \\
\hline $1550-1575$ & 162 & 142 & 128 & 432 & $6 \%$ \\
\hline $1575-1600$ & 402 & 405 & 408 & 1215 & $17 \%$ \\
\hline $1600-1625$ & 389 & 589 & 447 & 1425 & $20 \%$ \\
\hline $1625-1650$ & 346 & 520 & 483 & 1349 & $19 \%$ \\
\hline $1650-1675$ & 302 & 395 & 436 & 1133 & $16 \%$ \\
\hline $1675-1700$ & 274 & 156 & 279 & 709 & $10 \%$ \\
\hline $1700-1725$ & 171 & 85 & 106 & 362 & $5 \%$ \\
\hline $1725-1750$ & 71 & 50 & 24 & 145 & $2 \%$ \\
\hline $1750-1775$ & 35 & 6 & 11 & 52 & $1 \%$ \\
\hline $1775-1800$ & 3 & 0 & 0 & 3 & $0 \%$ \\
\hline $1800-1825$ & 0 & 0 & 0 & 0 & $0 \%$ \\
\hline $1825-2000$ & 0 & 1 & 0 & 1 & $0 \%$ \\
\hline total & 2187 & 2457 & 2358 & 7002 & $100 \%$ \\
\hline
\end{tabular}

\section{表 2 制動時のパンタ点電圧の度数分布}

Table 2. Frequency distribution of pantograph voltage at braking 


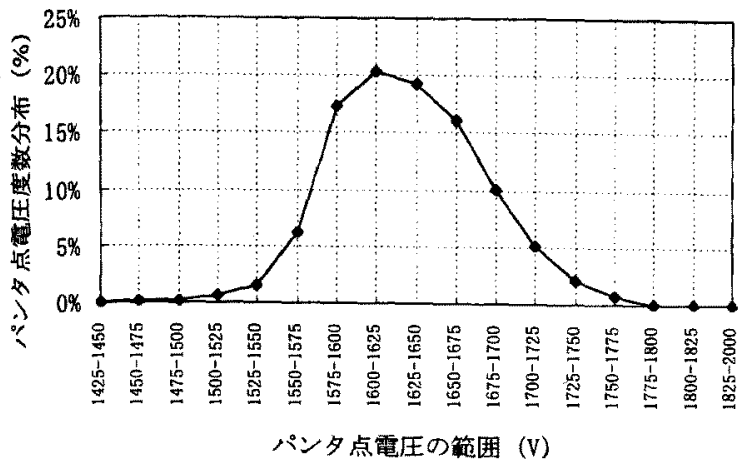

図 6 制動時のパンタ点電圧の度数分布

Fig. 6. Frequency distribution of pantograph voltage at braking

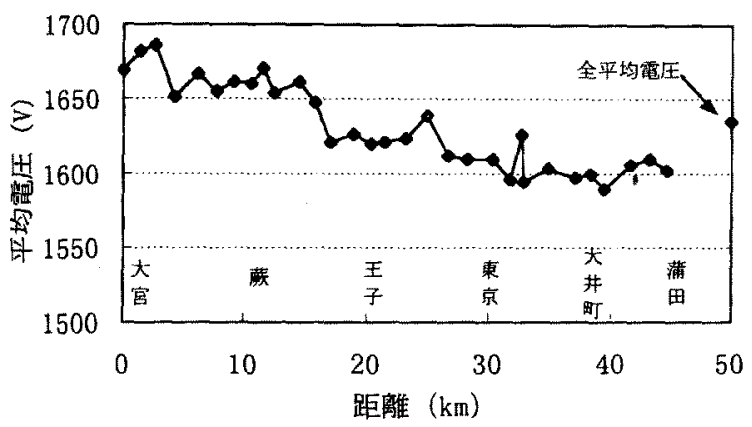

図 7 制動位置と制動時の平均パンタ点電圧

Fig. 7. Braking spot and average pantograph voltage at braking

<3・2> シミュレーション結果表 3 の前提条件もとに 回生有効率のシミュレーションを実施した。複線・複々線 で列車本数を変え,シミュレーション範囲を変えた時の回 生有効率のシミュレーション結果は，図8の通りである。

複線で 1 時間に往復 24 本の電車を走行させても図にある 通り回生有効率は 90\%程度である。複々線となり 1 時間に 合計往復 48 本の電車が走行する場合は, 回生有効率はほと んど 100\%近くになる。前述したように京浜東北線の実測 の回生有効率はほぼ $100 \%$ であった。これは京浜東北線が東 北線，山手線または東海道本線と並行し，複々線なり，3 複線になっており同一変電所からき電しているためや，他 線区と交差・分岥し同一変電所からき電している。このた め, 近傍の力行車に回生電力が吸収される確率が高くなり, 結果的にほとんど回生失効しないと考えられる。

今までの回生有効率のシミュレーション結果は若干低い
傾向があった ${ }^{(6)}$ ここれは，シミュレーション条件として複々 線としなかったことや交差線・分岐線考考虑しなかったこ とが，大きな原因と考えられる。

シミュレーション範囲は大宮を起点とし，大船方面へシ ミュレーションする範囲のことである。現実はシミュレー ション範囲などはなく起点方向，終点方向に直流電化区間 の続く限り伸びて行くと考えられる。シミェレーション範 囲が狭いと実際に適合した回生有効率にならない。図8に あるようにシミニレーションする範囲を拡大するにつれて 電車本数は増加し, 回生有効率は増加する。シミュレーシ ヨン範囲が狭い上，電車本数が少なすぎて現害に合った回 生有効率がシミュレーション結果として出ない。このため シミュレーション範囲は $40 \mathrm{~km}$ 程度以上の範囲を行う必要 がある。

また複線で電車を 24 本/時閒走行させるよりも同じ 24 本/時閒でも, 複々線で 1 複線当たり 12 本／時間, 合計 24 本／時間電車を走行させる方が図 8 にあるように回生有効 率は高くなる。これは複々線になることによりき電回路抵 抗が複線の時より低减することと, 回生車からの力行車へ の距離が複線の場合より短くなるためと考えられる。

今までシミュレーション範囲が狭いことや，複々線条件 等を入れないことで,シミュレーション結果の回生有効率が 低い場合があったが，このような条件を改善することによ り現実に合ったシミュレーションが行えるようになった。

表 $3 \mathrm{JR}$ 京浜東北線のシミュレーションの前提

Table 3 Conditions for the simulation of train operation on the JR Keihintohoku line.

\begin{tabular}{|c|c|}
\hline 条件 & 内容 \\
\hline 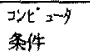 & 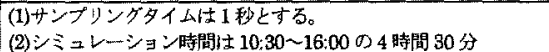 \\
\hline 線路条件 & 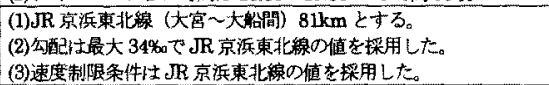 \\
\hline 電車条件 & 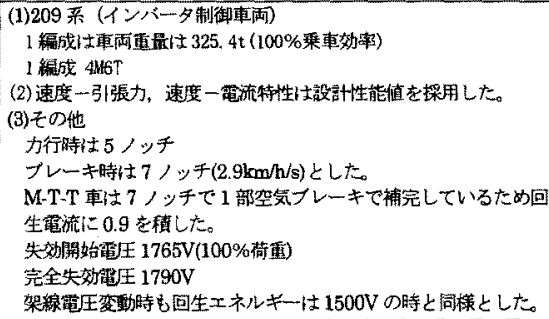 \\
\hline 通転条件 & 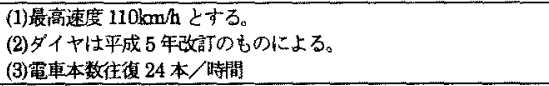 \\
\hline 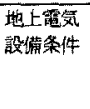 & 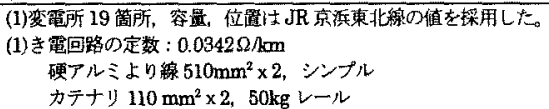 \\
\hline
\end{tabular}




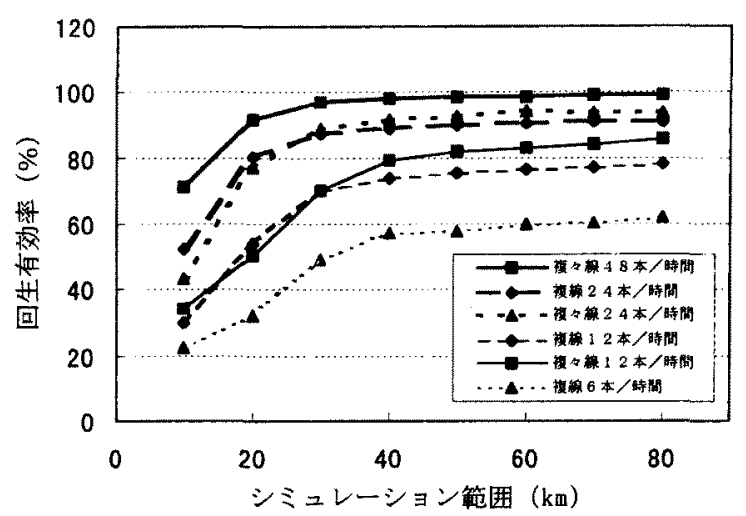

図 8 複々線・複線で列車本数, シミュレーション範囲 を変えた時の回生有効率

Fig. 8 The effective coefficent of regenerative energy on four-track lines and the double-track lines for different frequencies or train operation and different simulation ranges

\section{4. 閑散線区における回生有効率}

$<4 \cdot 1>$ 実测結果 1997 年 11 月 5 日(水), 6 日(木)の 2 日間，表 4 の通り塩尻〜甲府間でのスーパーあずさ号の 回生有効率の実測を行った。この区間は勾配が大きく，上 り列車・下り列車で勾配が大きく異なるため, 上り列車・ 下り列車で別々にデータを整理した。下りスーパーあずさ 号の各種電力量等と回生有効率は表 5, 図 9 の通りである。 回生有効率は同一列車であっても日によってかなり異なっ ており $30 \%$ $61 \%$ であり平均は $44 \%$ であった。上りスーパ 一あずさ号の各種電力量等と回生有効率は表 6 , 図 10 の通 りである。回生有効率は $42 \% \sim 68 \%$ であり平均は $54 \%$ であ った。上りスーパーあずさ号は，下り勾配のため制動頻度 が多く回生可能電力量は大きいが，対抗列車が上り勾配の ため力行の可能性が高いため，下りスーパーあずさ号より 回生有効率も高くなっている。前章の通勤線区は回生有効 率が 100\%近くであったが閑散線区は列車本数が少ないた めや，また当該線区を走行している他の列車が 9 両編成も しくは 3〜4 両編成のため，スーパーあずさ号の車両編成長 が他の列車に比して長く，回生電力が大きいため回生有効 率は $50 \%$ 前後と大幅に低下していた。
表 $4 \mathrm{JR}$ 中央東線における回生有効率測定の試験概要

Table 4 Outline of the test measure the effective coefficient of regenerative energy at the JR Chuotosen line

\begin{tabular}{|c|c|}
\hline 日時 & 1997 年 11 月 5 日(水), 6 日(木) \\
\hline 時間帯 & 8 時 27 分 19 時 40 分 \\
\hline 線区 & JR 中央東楾 甲府～塩尻間 $(85.83 \mathrm{~km})$ \\
\hline 車両 & E351 系インバータ制御車両 (6M $6 \mathrm{~T}$ ) \\
\hline 测定列車 & スーパーあずさ号 \\
\hline & $\begin{array}{l}1 \mathrm{M}, 9 \mathrm{M}, 11 \mathrm{M},(\text { 下り) }(1 \mathrm{M} \text {; 列車名) } \\
6 \mathrm{M}, 8 \mathrm{M}, 14 \mathrm{M}, \text { (上り) }\end{array}$ \\
\hline \multirow[t]{3}{*}{ 回生失効電圧 } & 失効開始電生 $1780 \mathrm{~V}$ \\
\hline & 完全失効電圧 $1830 \mathrm{~V}$ \\
\hline & （1780〜1830Vは比例でしぼり込む） \\
\hline
\end{tabular}

表 5 下りスーパーあずさ号（甲府〜塩尻）の各種電力量と 回生有効率

Table 5 Electric power consumed and the effective coefficient of regenerative energy of down Super Azusa train (Kofu-Shiojiri)

(1997/11/5,6 甲府一塩尻間)

\begin{tabular}{|c|c|c|c|c|c|c|c|}
\hline & $\begin{array}{c}\text { 消类電力量 } \\
(\mathbf{k} w \mathrm{~h})\end{array}$ & $\begin{array}{c}\text { 力行電力量 } \\
(\mathrm{k} W \mathrm{Wh})\end{array}$ & $\begin{array}{c}\text { 回生電力 } \\
(\mathrm{kWh})\end{array}$ & $\begin{array}{c}\begin{array}{c}\text { 㨔失電力是 } \\
(\mathrm{k} / \mathrm{h})\end{array} \\
\end{array}$ & 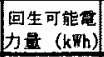 & $\begin{array}{c}0 \text { 回生率 } \\
(\%)\end{array}$ & $\begin{array}{c}\text { 回生有勃事 } \\
(\%)\end{array}$ \\
\hline IM $(11 / 5)$ & 1942 & 2165 & 223 & 264 & 487 & 10.3 & 45.8 \\
\hline IM $(11 / 6)$ & 1672 & 1864 & 192 & 253 & 445 & 10.3 & 43.1 \\
\hline $3 M(11 / 6)$ & 2214 & 2353 & 139 & 329 & 468 & 5. 9 & 29.7 \\
\hline $9 M(11 / 5)$ & 2082 & 2252 & 170 & 296 & 466 & 7.5 & 36.5 \\
\hline $9 M(11 / 6)$ & 1823 & 1998 & 175 & 199 & 374 & 8.8 & 46.8 \\
\hline $1 \mathrm{LM}(11 / 5)$ & 2001 & 2152 & 151 & 133 & 284 & 7.0 & 53.2 \\
\hline $11 /(11 / 6)$ & 1743 & 1982 & 239 & 152 & 391 & 12.1 & $6 \mathrm{~J} .1$ \\
\hline 平均 & 1925.3 & 2109.4 & 184.1 & 232.3 & 416.4 & 8.7 & 44.2 \\
\hline
\end{tabular}

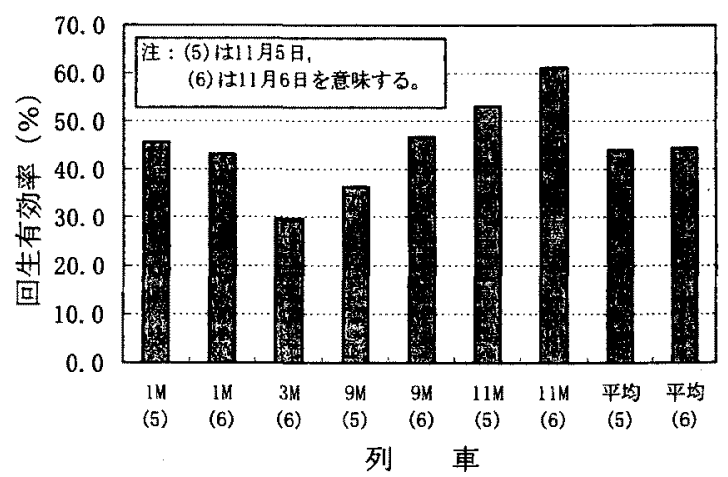

図 9 下りスーパーあずさ号（甲府〜塩尻）の回生有効率

Fig. 9. The effective coefficient of regenerative energy of down Super Azusa train (Kofu-Sioziri) 


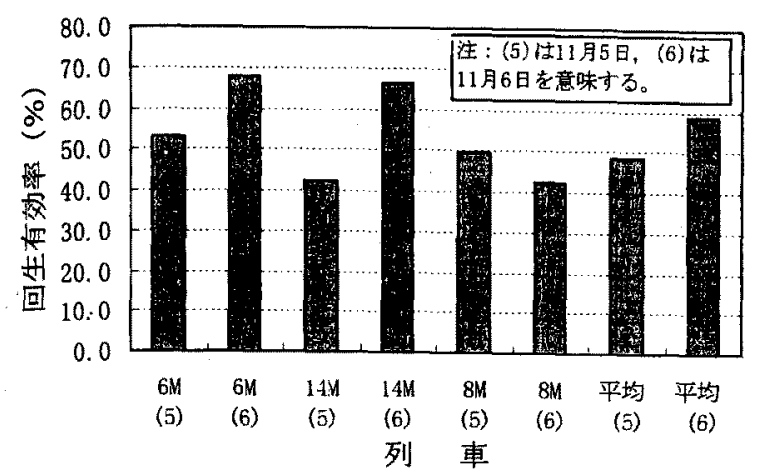

図 10 上りスーパーあずさ号（壏尻～甲府）の回生有効率

Fig. 10 The effective coefficient of regenerative energy of up Super Azusa train (Sioziri-Kofu)

表 6 上りスーパーあずさ号（塩尻〜甲付）の各種電力量と 回生有效率

Table 6 Electric power consined and the effective coefficient of regenerative energy of up Super Azusa train (Shiojiri-Kofu)

\begin{tabular}{|c|c|c|c|c|c|c|c|}
\hline & 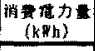 & $\begin{array}{c}\text { 力行要力直 } \\
(\mathrm{k} \text { 男h }\end{array}$ & 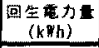 & 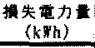 & 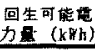 & $\begin{array}{c}\text { 回生揖 } \\
(8)\end{array}$ & $\begin{array}{c}\text { 回生有呩 } \\
(*)\end{array}$ \\
\hline$\theta 4(11 / 5)$ & 698 & 1086 & 388 & 339 & 727 & 35.7 & 53.4 \\
\hline 6h $(11 / 6)$ & 541 & 1016 & 475 & 225 & 700 & 46.8 & 67.9 \\
\hline $14 M(11 / 5)$ & 1011 & 1286 & 275 & 371 & 646 & 21.4 & 42.6 \\
\hline $14 M(11 / 6)$ & 647 & 1161 & 514 & 260 & 774 & 44.3 & 66.4 \\
\hline 8H $(11 / 5)$ & 803 & 1199 & 396 & 404 & 800 & 33.0 & 49.5 \\
\hline $8 M(11 / 6)$ & 946 & 1258 & 312 & 424 & 736 & 24.8 & 42.4 \\
\hline 平均 & 774.3 & 1167.7 & 393.3 & 337.2 & 730.5 & 33.7 & 53. 8 \\
\hline
\end{tabular}

<4・2> シミュレーション結果シミュレーション結 果を検証するために，実測結果とシミュレーションの比較 をおこなった。表 7 の前提条件のもとにシミュレーション を行った。結果は表 8 の通りであった。

力行電力量, 回生可能電力量などは実測よりシミュレー ション結果は多くなった。これはシミュレーションにおい ては実際の運転操檤ほど省エネルギ一を考慮した運転が出 来ない。すなわち列車が多少遅れていても前方に下り勾配 がある場合，笑際の場合情行のまま走行し下り勾配でゆ るやかな制動をするが，シミュレーションに拈いては前方 に勾配があることなどを考慮した運転論理になっていない ため，達れていれば力行し，勾配になれば強い制動をする ことよなるためである。

しかしながら回生有効率は実測の下り, 上りの平均が 44.2 ,
53.8\%であったが, シミュレーションにおいては，下りの 平均が $46.7 \%$, 上りの平均が $52.4 \%$ でありほぼ合っていた。 力行電力量等は実测結果とシミュレーション結果に若干 の差異があった。しかしながら回生有効率はほぼ合ってい たため,このシミュレーションモデルで回生有効率向上の 研究を行っても傾问はつかめると考えられる。このため次 章においてこのモデルで回生有効率向上の研究を行う。

表 $7 \mathrm{JR}$ 中央東線のシミュレーションの前提

Table 7. Conditions for the simulation to train operation on the JR Chuotosen line

\begin{tabular}{|c|c|}
\hline 禿件 & 太容 \\
\hline $\begin{array}{l}3 火^{*} x-4 \\
\text { 柴件 }\end{array}$ & 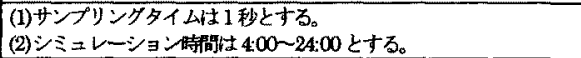 \\
\hline 線路条件 & 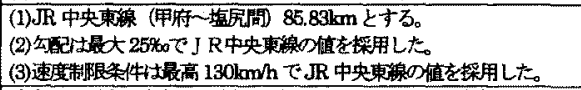 \\
\hline 䡛両㷛件 & 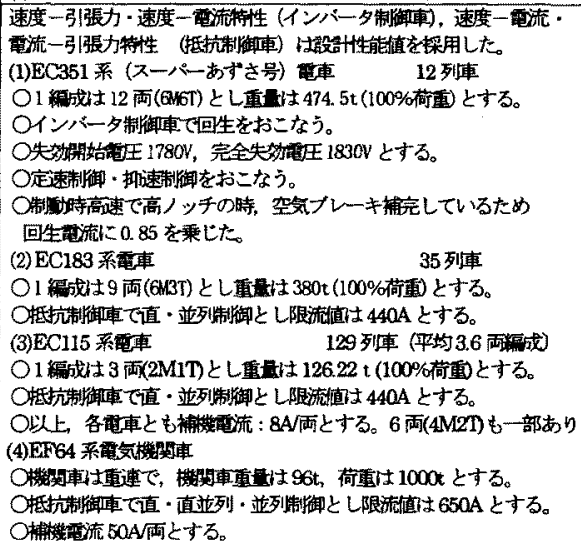 \\
\hline 通檕条件 & 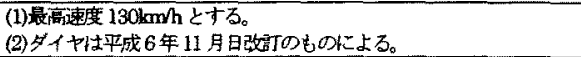 \\
\hline $\begin{array}{l}\text { 地上重気 } \\
\text { 設情条件 }\end{array}$ & 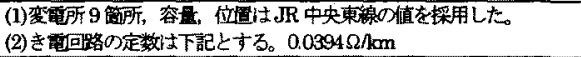 \\
\hline $\mathrm{M}$ & ：拈随車等，阳流值：直 \\
\hline
\end{tabular}

表 8 スーパーあずさ号（塩尻〜甲府）の各種電力量と 回生有効率のシミュレーション結果

Table 8 Simulation results of the electric power and the effective coefficient of regenerative energy of all Super Azusa trains (Sioziri-Kofu)

\begin{tabular}{|c|c|c|c|c|c|c|c|}
\hline & \multicolumn{3}{|c|}{ 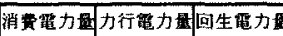 } & \multicolumn{2}{|c|}{ 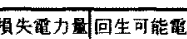 } & \multicolumn{2}{|c|}{ 回生科回生有効评 } \\
\hline & (kWh) & $(\mathrm{kWh})$ & $(\mathrm{k} w \mathrm{~h})$ & $(\mathrm{kWh})$ & 如 $\left(\mathrm{kWh}^{\mathrm{W}}\right.$ & (\%) & (\$) \\
\hline F平均 & 1903 & 2160 & 257 & 294 & 551 & 11.9 & 46.7 \\
\hline $\begin{array}{l}\text { 上り平均 } \\
(6,8,144)\end{array}$ & 839 & 1234 & 395 & 358 & 753 & 32,0 & 52. \\
\hline
\end{tabular}




\section{5. 閑散線区における回生有矨率向上策}

$<5 \cdot 1>$ 車両編成長を変えた場合ここの線区は大半が 3 両 編成の抵抗制御車であり，1 部 9 雨編成の抵抗制御車，電気 機関車が走行している。スーパーめずさ号は 12 画編成であ り，車両編成長が長く，制動時長大編成の大きな制動パワ 一が大きな回生電力となる。短編成の力行車両ではこの回 生電力を 1 部しか吸収できないため回生有効率は低下する。 この対策としてスーパーあずさ号の車両編成長を短くした 場合の回生有効率に与える影響をシミュレーションした。 結果は図 11 の通りであった。なお関連する力行電力量と回 生電力量の比, 回生率 (回生電力量/力行電力量) も示し た。

表 7 の前提にあるように，4 時から 24 時までシミュレー ションを行い，12 両編成の上り下り全スーパーあずさ号の 平均回生有効率は，50\%前後であるが，編成車両数を短く するにつれて回生有効率が向上し，4雨編成にすれば $80 \%$ 程度まで向上することがわかる。しかしながら車両編成長 を低减すれば乗務員の数が増加しコスト増となる問題があ る。両編成長を短くしなくても運転操繸時において, 制動・ 惰行，制動・情行というような断続的な制動を行わずに抑 速制御等を多く用い，連続的に制動をおこない制動パワー を小さくし，回生電力を小さくすれば回生有効率は向上す ると考えられる。

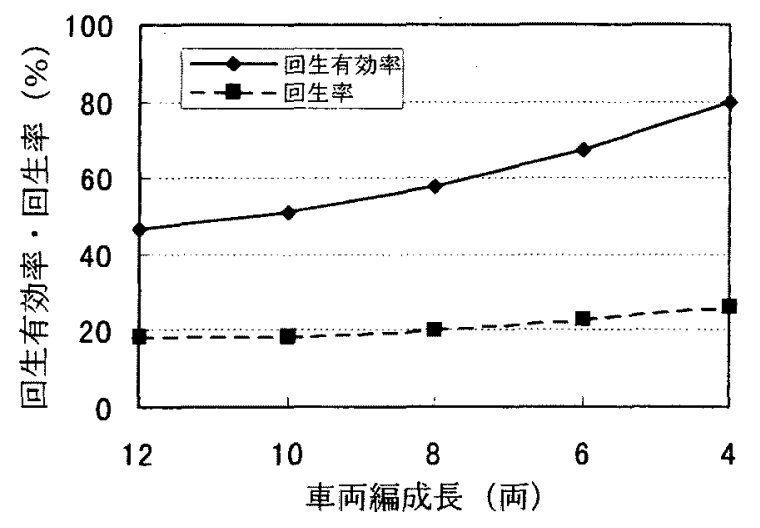

図 11 車両編成長を变えた回生有効率

Fig. 11 The effective coefficent of regenerative energy for different lengths of train composition

<5·2>インバータを設置した場合＼cjkstart各変電所にイン バー夕を設置した場合の回生有効率の研究をおこなった。 インバータ容量を変えた時の結果は，図 12 の通りである。
各変電所にインバータを設置した場合は約 $10 \%$ 強の回生有 効率の向上があった。インバー夕容量を増加させても，こ の容量の範囲では余り効果の変化はなかった。

インバー夕電圧（これと同等以上の電圧になればインバ 一タが回生電力を吸收する）を変えた時の回生効率の研究 を行った。困13 の通りである。インバー夕電圧を極力低下 させる方が，回生車のパンタ点電圧が回生失効に到らず, 回生有効率が向上することがわかる。しかしながら变電所 における無負荷送り出し電圧は，閑散線区などにおいては 变電所間隔が長いこともあり，1700V 程度にしている。こ のためインバー夕電圧を低下させるにしても，1730V 程度 が限界となる。

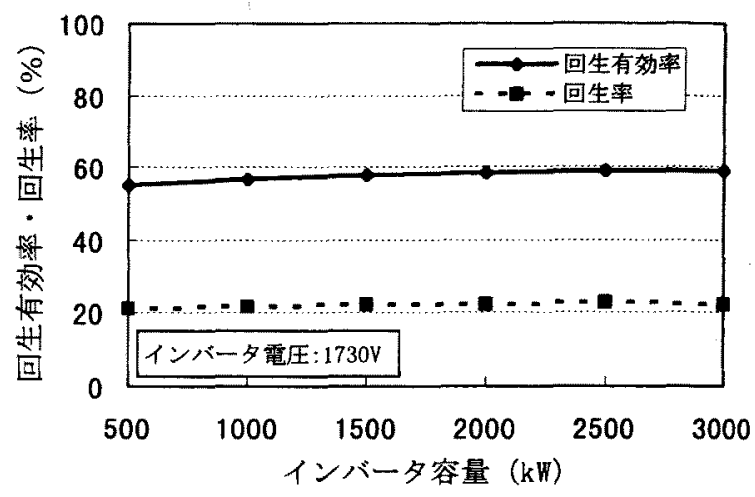

図 12 インバー夕容量を変えた時の回生有効率など

Fig. 12 The effective coefficient of regenerative energy and other measurements for different inverter capacities

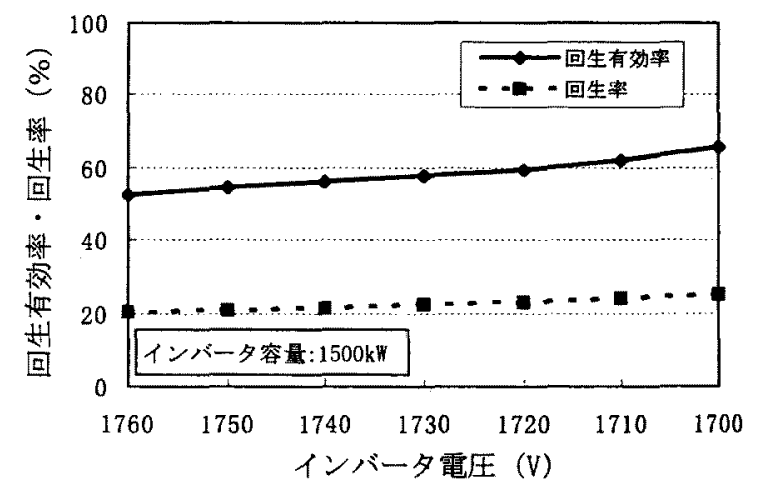

図 13 インバータ電圧を変えた時の回生有効率等など

Fig. 13 The effective coefficient of regenerative energy and other measurements for different inverter voltages 
<5・3> インバー夕設置の限界＼cjkstart前節で述べたインバ 一タを設置しても回生有効率は 100\%にならず，せいぜい $60 \%$ 前後でありかなりの限界がある。この問題を単純化し た変電所・回生車雨の配置で研究した。図 14 に変電所間に 回生車両のみが走行している単純化した図を示した。変電 所間隔など各值は JR 中央東線（甲府〜塩尻間）の平均的な 値である。

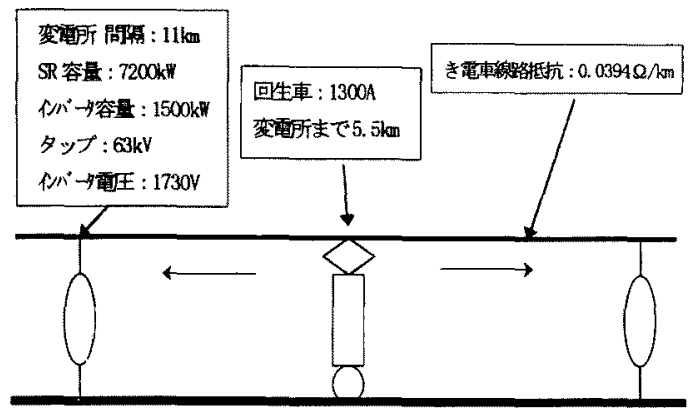

図 14 単純化した変電所・回生車両の配置図

Fig. 14 Simplified distribution of d.c. substations and regenerative vehicles

今, 回生車両が変電所中間を走行しているとする。表 7 の前提で示したように回生失効開始電圧 $1780 \mathrm{~V}$, 完全失効 電圧 $1830 \mathrm{~V}$ とすると，

回生有効率 $(\%)=(1830-\chi \chi) /(1830-1780) \times 100$

ここで $メ は ，$ 回生車両のパンタ点電圧 (V)

今,インバータ電圧は $1730 \mathrm{~V}$ であるため, パンタ点電圧は インバータ電圧に電圧降下を加えるため下式となる。

$\chi=1730+(1830-\chi) / 50 \times 1300 / 2 \times 0.0394 \times 5.5$

(17)式を解けばパン夕点電压は $1804 \mathrm{~V}$ となり，これを(16) 式に代入すれば回生有効率は求まり，52\%となる。このよ うにインバータを設置しても，回生有効率は 100\%になる のではなく，電車線路抵抗の電留降下の影響により一定の 限界があるのである。特に閑散線区においては変電所間隔 が長いため，電圧降下は大きくなりこの傾向は大きくなる。 この問題を別の角度から研究をおこなった。電車線路抵抗 の電圧降下の影響を相殺するために回生車両の失効開始電 圧を上昇させた時の検討をおこなった。

回生車両の失効開始電压を上昇させた時の回生有効率等 は図 15 の通りである。ここで, 完全失効電圧は回生失効開
始電圧 $+50(V)$ とした。失効開始電圧を上昇させれば大幅に 回生有効率は向上することがわかる。特にインバータを設 置した場合は，電車線路の電圧降下の影響を打ち消すため インバータを設置しない場合に比して，効果は特に大きく なる。ここで示したように電車線路抵抗の電圧降下の影響 がインバータを設置した場合の回生有効率の向上を妨げて いるのである。なお，現行車両設備等の高電圧の許容範囲 は $1900(V)$ 前後であり，これ以上にパンタ点電圧を上げるた めには，設備の改良をおこなう必要がある。

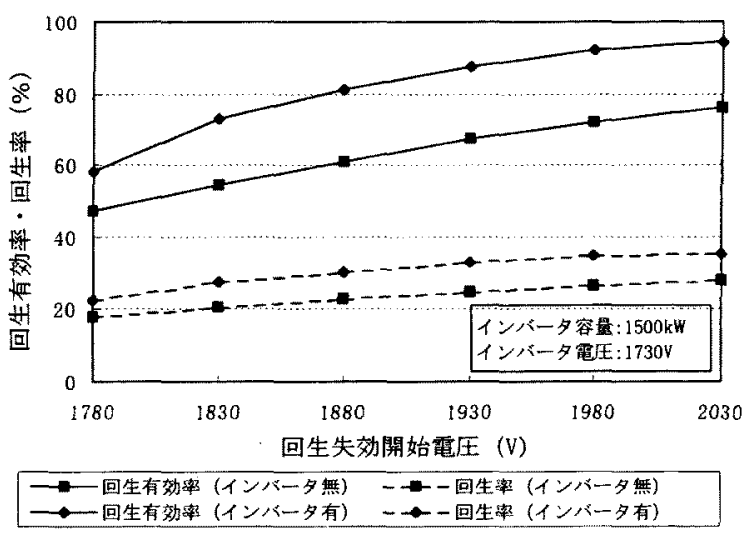

図 15 失効開始電圧を変えた時の回生有効率など

Fig. 15 The effective coefficient of regenerative energy and other measurements for different starting voltage of regeneration cancellation

<5・4>上下タイ, 上下一括き電方式にした場合等 変電所間隔を半分にした場合や上下タイ，上下一括き電方 式などき電方式を変えた場合で, 電車線路抵抗を変化され た場合やインバータの設置の有無の場合の検討をおこなっ t。

現在き電方式の場合は複線の上下線变電所で接続して いるだけである。上下タイき電方式は，変電所間隔の中間 付近で上下線を接続する方式であり，上下一括き電方式は 上下線を例えば，約 $200 \mathrm{~m}$ 間隔に接続する方式である。こ れらの方式は，き電回路の抵抗を下げるとともに回生電流 が上下線に相互に流れ易くし，回生有效率高离めのに効 果がある。検討結果は図16の通りである。

電車線路抵抗を低隇すれば，インバ一タの有無に拘らず 回生有効率は向上する。図から見てわかるようにインバー 夕を設置した場合は，インバー夕を設置しない場合に比べ 
て，電車線路抵抗の低減の効果がより大きくあらわれる。 特に上下一括き電方式等においては効果が顕著である。こ れはく5.3>節で述べたように電車線路抵抗の低減により回 生電力がインバー夕に吸収され易くなるためである。

インバータを設置しない場合，変電所間隔を $1 / 2$ にしても 上下タイき電システムより効果が下まわるのは, 回生車よ り，增加した変電所から力行車に多く電力を供給するため であると考えられる。

インバータを設置すれば，変電所閒隔を $1 / 2$ の場合，上下 タイき電システムより効果が上まわる。

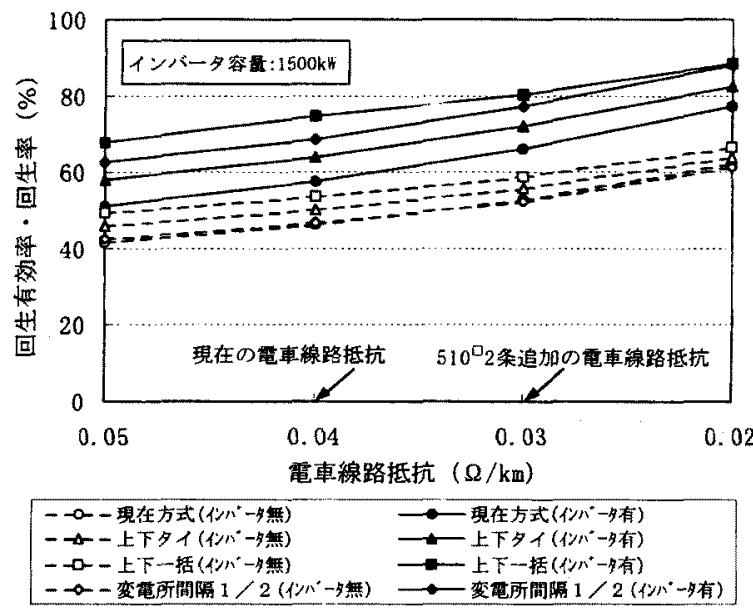

図 16 各種き電方式の回生有効率

Fig. 16 The effective coefficient of regenerative energy and for different feeding system

<5.5> 高電圧化をおこなった場合 現在 $1500 \mathrm{~V}$ で き電をおこなっているが，線路抵抗は変えないで $3000 \mathrm{~V}$ 等 高電圧化を行った場合の研究を行った。図 17 にあるように 高電压化を行うと大幅に回生有効率が改善することがわか る。これは高電圧化することによりき電々流が減少し，(回 生車より力行車までの電圧降下が半減するとともに, 回生 車のパンタ点電圧から回生失効開始電圧までの余裕が大き くなるためである。）4500V と昇圧するにつれて徐々に飽和 している。各変電所にインバータを設置した場合は同様の 理由で回生有効率が $100 \%$ に近づいている。当然電圧を上 昇させるにつれてき電損失等は半減する。

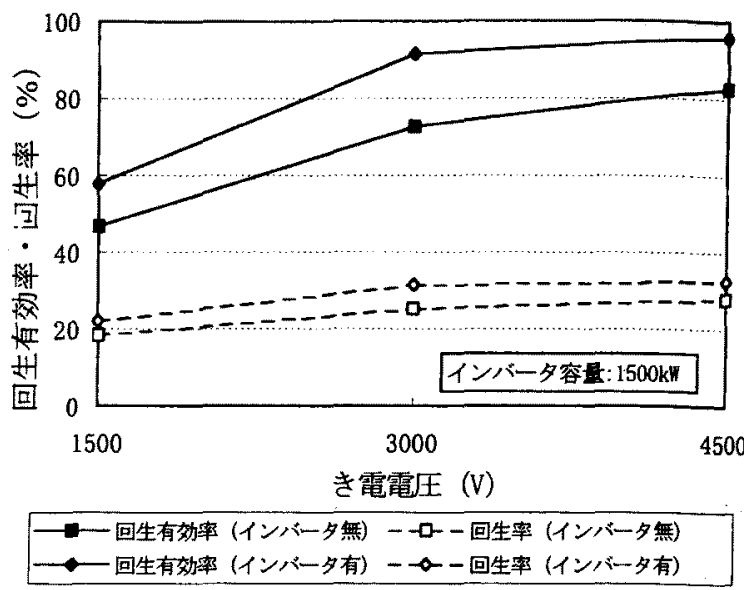

図 17 き電電圧を変えた時（昇圧）の回生有効率など

Fig. 17 The effective coefficient of regenerative energy and other measurements for different feeding voltages

6.まとめ

インバータ制御車のモデル化，回生有効率の測定及び向 上等の研究をおこない下記のことを明確にした。

(1)インバータ制御車はパンタ点電圧により引張力・制動力 が変化するが, その引張力・制動力の変化の特性, 及び その値より直流パンタ点電流を算出する方法を理論的に 明確にした。

(2) 回生有効率の測定及びシミュレーションを行ったが, 列 車本数, 車両編成長, 複々線等線区の状況によって回生 有効率が大幅に異なることがわかった。列車本数が多く 複々線， 3 複線の $\mathrm{JR}$ 京浜東北線では回生有效率ははほ $100 \%$ でった。一方列車本数が少なく回生車の編成両 数の長い JR 中央東線では回生有効率は約 $50 \%$ 前後であ った。

(3) 閔散線区の回生有効率の向上策としては車両編成長をそ の線区で走行している列車と同等程度の編成長にすれば 回生有効㻭は向上する。

(4) 各変電所にインバータ装置を設置すれば回生有効率は改 善するが, 変電所閒隔が長い場合限界がある。インバー 名装置を設置する場合も電車線路抵抗を低减するなり， 上下一括き電にするなどき電回路抵抗を低減すれば効果 が大きくなる。き電々压を高電圧化すればさらに回生有 効率は大幅に向上する。

䦥散線区においては，設備投資に大きな経費のかかるイ 
ンバータを設置しても回生有効率の向上には一定の限界が ある。このため今後回生有効率の向上をはかるためには, 車 载抵抗器に代わる回生可能な方式の開発や高電圧化の検討 をする必要がある。

謝辞

最後に, JR 京浜東北線, JR 中央東線における回生有効率 の測定にあって, JR 東日本運輸部車両課菅谷氏はじめ関倸 各位，及び長野支社など関係各位に協力していただいたこと を述べ哚く謝意を表します。

(平成 10 年 12 月 28 日受付, 平成 11 年 11 月 02 日再受付)

\section{文献}

(1) 日本国有鉄道・車両設計事務所, “207 系通勤形直流電車 説明書”, (1986.10)

(2)金原弘道, “JR 東日本 901 系通勤形直流電車”, 電気車の 科学, Vol.45, No.3, pp34-42, (1992.5) (3)中戸川貫二，鈴木康夫，川端俊夫，“次世代通勤電車の開 発”，東急車両技法第 42 号，pp28-39，(1992.9）

(4)前川義雄, “JR 東日本における VVVF インバータ制御車 両の開発 (上) (下)”, 電気車の科学, Vol.45, No.1, pp23 -29, Vol.45, No.2, pp18-22, (1992.1,2)

(5)園木武雄, “207 系通勤形直流電車 (上) (下)”, 電気車の 科学, Vol.40, No.1, pp17-23, Vol.40, No.2, pp26 $-36,(1992.1,2)$

(5) 杉本健, “省エネルギーのための直流変電所の電圧制御”, 電学論 D, 115 巻 -8 号, pp1053-1063，(1995.8)

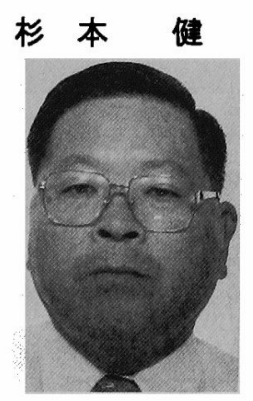

(正員) 1944 年 9 月 15 日生。 67 年京都 大学工学部電子工学科卒業。同年 4 月 国鉄入社。87 年鉄道技術研究所入所。 電気エネルギー研究室長、主幹。現在 三原菱重エンジニアリング技術顧問。 主として、き電システム、エネルギー、 制御関係の業務に従事。 